\title{
JPEB
}

\section{KETERKAITAN ANTARA CORPORATE SOCIAL RESPONSIBILITY TERHADAP MANAJEMEN LABA : SEBUAH PERSPEKTIF TEORI AGENCY}

\author{
Hayu Wikan Kinasih ${ }^{1 *}$, Melati Oktafiyani ${ }^{2}$ dan Lenni Yovita ${ }^{3}$ \\ ${ }^{1,2,3}$ Program Studi Akuntansi, Fakultas Ekonomi dan Bisnis, Universitas Dian Nuswantoro \\ Jalan Nakula I No. 5-11 Semarang, Indonesia \\ *Corresponding Author : hayu.wikan@dsn.dinus.ac.id
}

Diterima: April 2018; Direvisi: Juli 2018; Dipublikasikan: September 2018

\begin{abstract}
The aim of this study is to examine the impact of Corporate Social Responsibility (CSR), measured with Global Reporting Initiative (GRI) G4 index towards earning management, measured with discretionary accruals; with leverage, size, and ROA as a control variable.By using sample of 23 mining companies listed in Indonesia Stock Exchange over the period 2011 - 2015. Based on multiregression linear analysis, the study result show that CSR, leverage, and size has no impact on earning management. The otherhand, ROA has a significant impact on earning management.
\end{abstract}

Keywords : Corporate Social Responsibility; Earning Management; Discretionary Accruals; Leverage; Size; ROA

\section{ABSTRAK}

Studi ini bertujuan menguji pengaruh Corporate Social Responsibility (CSR) dengan indikator indeks Global Reporting Initiative (GRI) G4 terhadap manajemen laba dengan proksi discretionary accruals; variabel kontrol leverage, size dan ROA. Sampel yang digunakan sebanyak 23 perusahaan pertambangan yang terdaftar pada Bursa Efek Indonesia pada kurun waktu 2011 - 2015. Berdasarkan hasil pengujian regresi linier berganda menunjukkan bahwa tidak terdapat pengaruh antara CSR dengan manajemen laba, begitu juga dengan leverage dan size. Sedangkan variabel ROA menunjukkan adanya pengaruh signifikan terhadap manajemen laba.

Kata Kunci : Corporate Social Responsibility; Manajemen Laba; Discretionary Accruals; Leverage; Size; ROA 


\section{PENDAHULUAN}

Corporate Social Responsibility (CSR) merupakan sebuah bentuk tuntutan para pemangku kepentingan mengenai transparansi pelaporan dampak bisnis perusahaan terhadap lingkungan. Tuntutan tersebut kemudian bergerak menjadi sebuah kewajiban bagi entitas bisnis untuk ikut andil dalam operasionalisasi korporasi dengan tujuan untuk memberikan kenyamanan bahkan memberikan kesejahteraan bagi masyarakat luas. Tanggung jawab terhadap lingkungan perusahaan ini bermula dari keprihatinan atas dampak operasi perusahaan dalam aspek sosial, ekonomi, dan lingkungan. Pemerintah Indonesia mendukung adanya pelaksanaan CSR melalui Undang - Undang (UU) No. 40 Tahun 2007 pasal 74, yang dipertegas dengan Peraturan Pemerintah No. 47 Tahun 2012.

Dalam sebuah isu yang mengemuka, dikatakan bahwa perusahaan yang melakukan CSR akan dianggap sebagai perusahaan yang berperilaku etis. Sehingga akan sangat mustahil bagi perusahaan tersebut untuk melakukan pelanggaran, misalnya seperti melakukan manipulasi laba atau bahasa populernya adalah manajemen laba.

Tindakan manajemen laba merupakan sebuah aksi manajemen internal untuk merekayasa laporan keuangan perusahaan dengan cara menaikkan atau menurunkan laba. Tujuan dari tindakan ini adalah untuk memberikan informasi kepada investor mengenai kinerja ekonomi perusahaan yang dihasilkan pada tahun tersebut (Evadewi \& Meiranto, 2014). Khan, et.al (2012) menyatakan bahwa tindakan manajemen laba oleh perusahaan dalam lingkup yang besar akan menghasilkan kualitas laba yang rendah begitu juga sebaliknya. Dapat dikatakan bahwa manajemen laba perusahaan mengakibatkan laporan keuangan tidak lagi mampu memberikan informasi perusahaan yang akurat (Chih, et.al, 2008). Sebagai akibatnya, investor akan memperoleh informasi yang dirasa menyesatkan sehingga keputusan yang diambil juga akan keliru.

Laporan keuangan perusahaan sendiri merupakan salah satu hal yang dianggap sangat penting bagi para pengambil keputusan di dalam sebuah entitas bisnis. Hal ini dikarenakan, laporan keuangan memuat tentang informasi yang digunakan untuk melakukan penilaian atas kinerja perusahaan. Selain itu, laporan keuangan juga bermanfaat untuk mengetahui seberapa besar posisi keuangan perusahaan, serta menarik minat investor untuk berinvestasi dalam perusahaan. Dalam rangka memunculkan minat investor tersebut, sebuah perusahaan harus menunjukkan kinerja serta posisi yang baik. Kinerja perusahaan yang baik tersebut, akan membantu stakeholder dalam membuat keputusan (Healy \& Wahlen, 2009). Hal yang menjadi materi pertimbangan investor dalam mengeksekusi investasi pada korporasi yaitu besaran laba yang dihasilkan oleh operasional perusahaan.

Laba tersebut meupakan sebuah pencerminan kinerja suatu perusahaan pada suatu periode waktu. Dengan adanya laba, investor dapat meramalkan keberlanjutan sebuah perusahaan di masa yang akan datang. Dikarenakan tingginya kebergantungan yang tinggi atas laba oleh investor inilah yang menjadi sebuah motivasi bagi manajemen perusahaan untuk menunjukkan kinerja laba yang baik. Namun, hal ini juga menjadi salah satu motivasi bagi manajemen untuk melakukan manajemen laba.

Berdasarkan perspektif teori keagenan yang diungkapkan oleh Jensen and Meckling dinyatakan bahwa tindakan manajemen perusahaan dalam melakukan CSR dipandang sebagai sebuah tindakan oportunistik. Tindakan oportunistik yang dimaksud adalah bahwa CSR dilakukan oleh manajer sebagai salah satu tindakan yang dapat memberikan keuntungan pada pribadi manajer seperti misalnya adalah upaya peningkatan karirnya (Mc.Williams et al, 2006). CSR dapat dijadikan sebagai sebuah alat yang digunakan untuk menutupi tindakan tidak etis 
Hayu Wikan Kinasih, Melati Oktafiyani, dan Lenni Yovita :Keterkaitan Antara Corporate Social Responsibility Terhadap Manajemen Laba : Sebuah Perspektif Teori Agency

yang dilakukan perusahaan. Contohnya adalah tindakan manajemen laba yang dilakukan oleh perusahaan berikut ini :

Tabel 1.Tindakan Manajemen Laba

\begin{tabular}{llll}
\hline Tahun & Perusahaan & Kasus & \\
\hline 2011 & PT Elnusa & $\begin{array}{l}\text { Terdapatnya laporan bahwa perusahaan memiliki } \\
\text { cadangan sebesar Rp 111 Milyar, padahal sesungguhnya } \\
\text { perusahan mengalami kerugian (finance.detik.com, }\end{array}$ \\
& & 2017) \\
2012 & PT Bumi Resources, & $\begin{array}{l}\text { Penurunan harga saham PT BUMI yang seharusnya } \\
\text { mengikuti adanya penurunan laba atau sebab lain. }\end{array}$ \\
& Tbk (BUMI) & $\begin{array}{l}\text { Namun ternyata data laporan keuangan PT BUMI } \\
\text { menunjukkan adanya peningkatan laba }\end{array}$ \\
& & (www.neraca.co.id, 2017). & \\
\hline
\end{tabular}

Kedua perusahaan tersebut adalah perusahaan yang aktif dalam kegiatan CSR dan juga selalu melakukan pengungkapan atas aktivitas CSR yang dilakukan perusahaannya, namun fakta membuktikan kedua perusahaan tersebut juga melakukan tindakan tidak etis. Dari contoh kasus tersebut dapat dilihat bahwa tidak semua aktivitas CSR benar - benar merupakan bentuk tanggung jawab perusahaan atas dampak yang timbul atas operasinya saja, melainkan juga dapat dijadikan sebagai sebuah perilaku oportunistik perusahaan untuk memperlihatkan kepada investor tentang kinerjanya.

Khan, et.al (2012) menguji adanya pengaruh pengungkapan CSR terhadap manajemen laba. Hasil studi menunjukkan bahwa tingkat pengungkapan CSR terhadap manajemen laba dengan indikator akrual diskresioner ternyata berpengaruh positif. Hal tersebut berbeda dengan hasil studi Arief dan Ardiyanto (2014) yaitu tidak terdapat pengaruh pengungkapan CSR terhadap manajemen laba yang diproksikan dengan descrisonery accrual. Sedikit berbeda dengan studi yang dilakukan oleh Yip, et.al (2011) yang menguji hubungan pelaporan Corporate Social Responsibility dengan manajemen laba dalam lingkungan yang terfokus pada politik. Studi tersebut menemukan bahwa terdapat korelasi yang negatif antara pelaporan Corporate Social Responsibility dengan manajemen laba pada kelompok perusahaan minyak dan gas, serta korelasi positif pada kelompok perusahaan pangan. Keduanya signifikan pada level $5 \%$.

Evadewi \& Meiranto (2014) melakukan pengujian terhadap pengungkapan CSR terhadap manajemen laba yang berkaitan dengan political cost dengan menggunakan Size perusahaan, leverage, ROA, Growth sebagai variabel kontrol. Hasil studi menemukan bahwa pengungkapan CSR berpengaruh positif terhadap manajemen laba pada kelompok industri manufaktur dan signifikan pada level 5\%. Sedangkan hasil riset pada kelompok industri pertambangan menunjukkan bahwa CSR mempunyai pengaruh yang negatif signifikan terhadap manajemen laba.

Beberapa penelitian diatas merupakan replikasi penelitian yang dilakukan Khan, et. al, (2012) dengan menambah Return on Asset (ROA), leverage dan size sebagai variabel kontrol. Topik ini menjadi penting diteliti dikarenakan CSR merupakan topik yang saat ini masih hangat serta adanya indikasi praktik CSR yang dijadikan kedok bagi perusahaan untuk melakukan tindakan tidak etis, seperti manajemen laba. Penelitian ini diharapkan mampu menjawab ketidak konsistenan hasil penelitian dengan menggunakan perspektif teoritis dengan sampel perusahaan pertambangan yang terdaftar dalam Bursa Efek Indonesia. 


\section{TINJAUAN PUSTAKA}

\section{Corporate Social Responsibility}

Corporate Social Responsibility (CSR) atau tanggung jawab sosial perusahaan adalah sikap perusahaan yang memegang komitmen pada stakeholders perusahaan untuk melakukan tanggung jawabnya atas dampak operasi perusahaan. Tinjauan elemen CSR terletak pada unsur sosial, ekonomi, maupun lingkungan. Tanggung jawab sosial perusahaan menurut The World Business Council for Sustainable Development adalah sebuah komitmen bisnis yang terus menerus dilakukan oleh perusahaan untuk bertindak etis serta mampu memberikan sumbangsih dalam pembangunan ekonomi dan peningkatan kualitas hidup karyawan, masyarakat lokal serta seluruh lapisan masyarakat

John Elkington mengembangkan sebuah konsep yang disebut sebagai triple bottom line pada tahun 1997. Dalam triple bottom line menyatakan bahwa setiap entitas bisnis harus menerapkan kosep 3P, dimana selain berfokus pada penciptaan laba (profit), perusahaan juga harus memperlihatkan keterlibatannya dalam memenuhi kesejahteraan masyarakat (people) serta menjaga kelestarian lingkungan (planet).

\section{Manajemen Laba}

Manajemen laba (earning management) adalah langkah-langkah bisnis para manajer untuk merekayasa laporan keuangan dengan unsur kesengajaan dan dalam batas yang diperbolehkan oleh prinsip-prinsip akuntansi. Langkah tersebut bertujuan untuk menyediakan informasi yang tidak benar bagi para pemangku kepentingan (stakeholders) untuk kepentingan para manajer (Meutia, 2004). Sedikit berbeda dengan Healy dan Wahlen (1999) yang memaknai manajemen laba sebagai sebuah langkah yang dilakukan saat para manajer menggunakan keputusan tertentu dalam mendisklosur laporan keuangan dan dengan sengaja mengubah transaksi yang berkaitan dengan laporan keuangan sehingga para pemangku kepentingan merasa perlu mengetahui kinerja keuangan perusahaan mendapatkan informasi yang tidak benar. Hal ini mengakibatkan terpengaruhnya keputusan stakeholder tersebut sebagai akibat dari angka - angka akuntansi yang dilaporkan.

\section{Perumusan Hipothesis}

Dalam pelaksanaannya aktivitas CSR perusahaan tidak dapat terlepas dari peran serta dan dukungan masyarakat. Selain CSR ini digunakan sebagai sebuah aktivitas untuk membantu masyarakat serta lingkungan, CSR juga digunakan sebagai sebuah alat untuk membentuk profil organisasi yang baik. Tindakan CSR bagi manajer yang memiliki kepentingan, akan dijadikan sebagai sebuah alat untuk meutupi tindakan negatif yang dilakukannya, seperti misalnya manajemen laba. CSR yang dilakukan oleh perusahaan digunakan untuk memberikan informasi yang seolah - olah tidak menyesatkan bagi stakeholder, namun ternyata menyesatkan.

Hasil penelitian Arief dan Ardiyanto (2014) menghasilkan temuan bahwa tidak terdapat pengaruh yang signifikan dari pengungkapan CSR terhadap manajemen laba (DAC). Penelitian tersebut menggunakan variabel kontrol leverage, growth, dan return on assets. Disisi lain, penelitian Evadewi dan Meiranto (2014) menemukan bahwa terdapat pengaruh yang positif dan signifikan dari pengungkapan CSR terhadap manajemen laba pada kelompok industri manufaktur. Berdasarkan hasil-hasil penelitian terdahulu diatas, maka hipotesis penelitian ini adalah :

$\mathrm{H}_{1}$ : Pengungkapan tanggung jawab sosial perusahaan berpengaruh signifikan terhadap manajemen laba. 
Hayu Wikan Kinasih, Melati Oktafiyani, dan Lenni Yovita :Keterkaitan Antara Corporate Social Responsibility Terhadap Manajemen Laba : Sebuah Perspektif Teori Agency

\section{Kerangka Pemikiran Teoritis}

Manajemen laba merupakan suatu tindakan yang dilakukan oleh manager dengan cara meningkatkan atau menurunan laba pada laporan keuangan perusahaan. Keberadaan manajemen laba yang dilakukan oleh perusahaan ini akan mengakibatkan informasi yang diperoleh oleh stakeholder menjadi bias, sehingga keputusan yang dibuat oleh stakeholder-pun menjadi tidak tepat. (Healy dan Wahlen, 1999). Transparansi informasi yang disajikan manajemen perusahaan dalam pelaporan perusahaan termasuk didalamnya adalah pelaporan mengenai aktivitas CSR. Aktivitas CSR ini menurut konsep teori keagenan merupakan sebuah bentuk kepedulain perusahaan terhadap lingkungan, masyarakat dan sosial. Namun aktivitas ini diikuti oleh kepentingan pribadi manajer perusahaan agar atekholder menilai kinerja yang dilakukannya di dalam perusahaan tersebut baik. Sebagai akibatnya, manajer akan menerima insentif atas kinerjanya tersebut. Dalam penelitian ini pengukuran manajemen laba menggunakan discretionary accruals, sedangkan aktivitas CSR perusahaan dinilai melalui pengungkapan informasi yang dilakukan oleh perusahaan yang diukur dengan menggunakan pengindeksan Global Reporting Initiative (GRI) G4 Sustainability Reporting Guidelines. Penelitian ini juga melibatkan tiga veriabel kontrol yang dianggap memiliki peran terhadap dilakukannya manajemen laba pada perusahaan, antara lain : leverage, size, dan ROA.

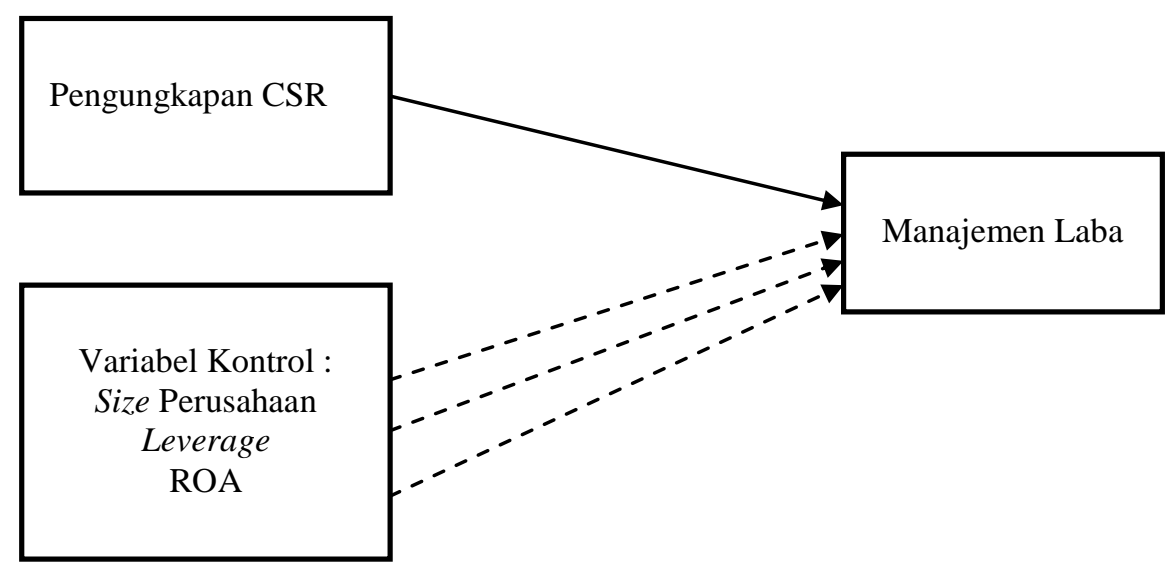

\section{Gambar 1.Kerangka Pemikiran}

\section{METODE PENELITIAN}

Penelitian ini menggunakan variabel independen CSR, variabel dependen manajemen laba dan variabel kontrol leverage, size dan ROA. Variabel CSR diukur dengan menggunakan pengungkapan informasi yang disampaikan perusahaan yang dinilai dengan menggunakan indeks GRI 4. Nilai CSR diperoleh dari jumlah item pengungkapan yang diungkapkan oleh perusahaan didalam laporan tahunannya dibagi dengan jumlah item keseluruhan.

$$
\text { Indeks CSRDj }=\sum_{t=1}^{n j} X_{i j} / n_{j}
$$

Variabel manajemen laba diproksi dengan menggunakan modified discretionary accrual yang dikembangkan oleh Jones. Untuk menentukan besarnya manajemen laba dengan menggunakan rumus sebagai berikut : 
Menentukan besarnya Total Accrual

\section{TACit $=$ NIit - CFOit}

TACit merupakan Total akrual perusahaan, sedangkan Nlit merupakan Laba bersih setelah pajak perusahaan dan CFO adalah arus kas yang diperoleh dari kegiatan operasi perusahaan. Langkah selanjutnya dalam menghitung DA adalah dengan menentukan besarnya koefisien. Penentuan besarnya koefiesien ini dapat dilakukan dengan menggunakan regresi antara total akrual perusahaan (TACit) dengan total aset periode sebelumnya (Tat-1), perubahan pendapatan ( $\triangle \mathrm{REVit}$ ), perubahan total piutang ( $\triangle \mathrm{RECit})$ dan besarnya PPE (Plant, Property, Equipment), seperti pada persamaan berikut :

\section{TACit/TAit-1 = $\beta 1(1 /$ TAit-1 $)+\beta 2((\Delta R E V i t ~-~ \triangle R E C i t ~) /$ TAit-1 $)+\beta 3($ PPEit $/$ TAit-1 $)+$ عit}

Setelah menentukan besarnya koefisien, selanjutnya diperhitungkanah besarnya nilai Non-discretionary Accrual (NDACt)

$$
N D A C t=\alpha_{0} \frac{1}{T A_{t-1}}+\alpha
$$

Yang terakhir adalah menentukan besarnya discretionary accrual (DAC)

$$
\text { DAC }=(\text { TAC/TAit-1) }- \text { NDAC }
$$

Variabel kontrol size diukur dengan menggunakan log Total Asset sebagaimana yang pernah digunakan oleh Muttakin dan Khan (2015), Evadewi dan Meiranto (2014), Yip et al. (2011) dan Kim et al. (2012). Formula variabel kontrol, leverage yaitu total hutang dibagi dengan total ekuitas perusahaan. Sedangkan formula variabel Return On Assets (ROA) yaitu laba bersih sebelum pajak (EBT) dibagi dengan dengan total aset (Kim, et.al, 2012).

Pengambilan sampel dilakukan dengan purposive sampling dengan obyek penelitian adalah laporan tahunan perusahaan pertambangan yang terdaftar di Bursa Efek Indonesia pada kurun waktu 2011 - 2015. Selanjutnya sampel diolah dan dianalisis dengan metode regresi linier berganda. Menurut Ghozali (2016), analisis regresi linier berganda mengukur kekuatan hubungan antara dua variabel atau lebih, serta untuk menunjukkan arah hubungan antara variabel bebas (independen) dan variabel terikat (dependen). Berikut model regresi berganda yang digunakan dalam studi ini :

$$
Y=\alpha+\beta_{1} \mathbf{x}_{1}+\beta_{2} \mathbf{x}_{2}+\beta_{3} \mathbf{x}_{3}+\beta_{4} \mathbf{x}_{4}+\varepsilon
$$

Dimana,

$\mathrm{Y} \quad=$ manajemen laba;

$\alpha \quad=$ konstanta;

$\beta 1, \beta 2, \beta 3, \ldots=$ koefisien persamaan regresi;

$\mathrm{x}_{1} \quad=$ indeks CSR;

$\mathrm{X}_{2} \quad=$ ukuran perusahaan;

$\mathrm{x}_{3} \quad=$ leverage;

$\mathrm{x}_{4} \quad=$ Return on Asset perusahaan i pada tahun $\mathrm{t}$

$\varepsilon \quad=\operatorname{error}($ Kesalahan Penggangu) 
Hayu Wikan Kinasih, Melati Oktafiyani, dan Lenni Yovita :Keterkaitan Antara Corporate Social Responsibility Terhadap Manajemen Laba : Sebuah Perspektif Teori Agency

\section{HASIL DAN PEMBAHASAN}

Pada tahapan sebelum pengujian analisis regresi berganda, akan dilakukan pengujian uji asumsi klasik. Uji asumsi klasik dilakukan agar mengetahui model penelitian yang layak. Tahapan uji asumsi klasik meliputi uji normalitas, uji multikolonieritas, uji heteroskedastisitas, uji autokorelasi. Hasil dari pengujian asumsi klasik adalah sebagai berikut :

Tabel 2. Hasil Pengujian Asumsi Klasik

\begin{tabular}{lcccc}
\hline Dependen Variabel : DA & \multicolumn{4}{c}{ Variabel } \\
\hline & CSR & Leverage & Size & ROA \\
VIF & 1,007 & 1,027 & 1,053 & 1,027 \\
Tolerance & 0,993 & 0,974 & 0,950 & 0,974 \\
Glejser (Sig) & 0,154 & 0,420 & 0,062 & 0,595 \\
Kolmogorov-Smirnov (Sig) & \multicolumn{4}{c}{0,253} \\
Durbin Watson & \multicolumn{5}{c}{1,936} \\
\hline
\end{tabular}

Dari hasil pengujian tersebut dapat dilihat bahwa nilai untuk semua pengujian asumsi klasik memenuhi batas yang telah ditetapkan. Dapat dikatakan bahwa data telah layak untuk digunakan dalam pengujian selanjutnya. Uji model yang dilakukan dengan menggunakan uji simutan, parsial, dan ketergantungan model (koefisien determinasi) menunjukkan hasil sebagai berikut :

Tabel 3. Hasil Uji t, Uji F dan $\mathbf{R}^{2}$

\begin{tabular}{lcc}
\hline & T & Sig \\
\hline CSR $\rightarrow$ DA & $-0,315$ & 0,126 \\
leverage $\rightarrow$ DA & $-2,916 \mathrm{E}-006$ & 0,779 \\
Size $\rightarrow$ DA & $-0,008$ & 0,529 \\
ROA $\rightarrow$ DA & 0,531 & 0,000 \\
F $=3,543$ & & 0,000 \\
AdjustedR Squared & 0,351 & \\
\hline
\end{tabular}

Dari hasil pengujian tersebut, maka dapat dibentuk sebuah persamaan regresi dengan melihat nilai koefisien B pada kolom Unstandardized Residual. Persamaan yang terbentuk adalah sebagai berikut :

$$
\text { DA = 0,138 - 0,315 CSR - 2,916E-006 LEVERAGE - 0,008 SIZE + 0,531 ROA + e }
$$

Hasil uji simultan (uji F) menunjukkan nilai signifikansi F sebesar 0,000. Hal tersebut berarti bahwa model pengujian regresi dengan menggunakan variabel independen csr, leverage, size dan ROA dan variabel dependen manajemen laba (DA) dapat dikatakan fit. Angka ketergantungan dari nilai keseleuruhan variabel bebas terhadap variabel terikat adalah sebesar $35,1 \%$. Nilai ini dikatakan nilai yang cukup rendah untuk menjelaskan hubungan antara variabel independen dan variabel dpenden yang digunakan dalam pengujian. Sehingga dapat diduga bahwa, ada variabel indpenden lain yang nilainya lebih dapat menjelaskan tentang variabel dependen Discretionary Accrual.

Hasil uji parsial dalam penelitian ini menunjukan bahwa tidak ada pengaruh dari Variabel CSR terhadap manajemen laba, sehingga hasil studi ini menolak $\mathrm{H}_{1}$. Akan tetapi dari ketiga variabel kontrol leverage, size, dan ROA, hanya ROA yang menunjukkan adanya pengaruh terhadap manajamen laba, sedangkan leverage dan size tidak. 
Pengungkapan informasi mengenai aktivitas tanggung jawab sosial perusahaan (CSRD) diukur dengan menggunakan Index Global Reporting Initiative (GRI) G4 yang terdiri dari 91 aspek. Dari beberapa aspek yang terdapat dalam panduan pelaporan GRI 4, ditemukan bahwa baru sedikit aspek yang diungkapkan oleh perusahaan - perusahaan di Indonesia. Dalam kaitannya dengan manajemen laba, semua aspek tersebut sangatlah wajib diungkapkan karena perusahaan berusaha untuk mendapatkan citra positif dari masyarakat. Dari kategori ekonomi misalnya, aspek keberadaan pasar sangat sedikit diungkapkan. Sedikitnya pengungkapan yang dilakukan ini dikarenakan tidak adanya aturan yang mengatur dengan jelas apa saja yang harus diungkapkan oleh perusahaan.

Penelitian ini mendukung penelitian yang sebelumnya dilakukan oleh Arief dan Ardiyanto (2014) yang berpendapat bahwa pengungkapan CSR tidak memiliki pengaruh terhadap manajemen laba (DAC). Manajemen laba dilakukan melalui pengelolaan akrual laporan keuangan perusahaan, yang dilakukan dengan menaikkan atau menurunkan laba. Manajer yang memiliki self-interest terhadap perusahaan umumnya mempunyai kecenderungan untuk mendapatkan keuntungan melalui pelaksanaan dan pengungkapan CSR demi mendapatkan pengakuan atas prestasi pribadi manajer. Namun, hasil penelitian ini tidak menunjukkan adanya dukungan atas hubungan empiris antara pengungkapan CSR dengan tindakan manajemen laba manajer perusahaan.

Hasil pengujian terhadap variabel kontrol yaitu leverage, size dan ROA, menunjukkan bahwa hanya ROA satu - saunya yang berpengaruh terhadap manajemen laba. Hal ini menunjukkan bahwa ketika perusahaan semakin dapat menciptakan laba yang tinggi melalui aset yang dimilikinya, maka semakin tinggi kemungkinan perusahaan untuk melakukan manajemen laba dengan meningkatkan laba yang dilaporkan.

\section{SIMPULAN}

Berdasarkan hasil penelitian yang dilakukan terhadap 23 perusahaan pertambangan yang terdaftar di Bursa Efek Indoesia selama periode tahun 2011 - 2015, diperoleh hasil yang menunjukkan tidak adanya keterkaitan antara aktivitas CSR yang ditunjukkan dengan besarnya pengungkapan dengan menggunakan indeks GRI-4 dengan manajemen laba yang diukur dengan menggunakan discretionary accrual. Hasil ini belum mampu memberikan bukti empiris yang mampu mendukung tindakan manajemen laba manajer melalui aktivitas CSR. Penelitian ini masih memiliki keterbatasan pada jumlah data serta alat yang dipergunakan untuk mengukur CSR, sehingga disarankan bagi penelitian selanjutnya dapat mengembangkan alat pengukuran kuantitatif untuk menentukan ketepatan menilai CSR.

\section{DAFTAR PUSTAKA}

Arief, A., Ardiyanto, D.M. 2014. Pengaruh Pengungkapan Corporate Social Responsibility Terhadap Manajemen Laba : Study Kasus Pada Perusahaan Non Keuangan Dan Jasa Yang Terdaftar Di BEI Tahun 2010-2012. Diponegoro Journal of Accounting.

Chih, H., Shen, C.H., Kang, F.C. 2008. Corporate Social Responsibility, Investor Protection, and Earning Management : Some International Evidence. Journal of Business Ethics.

Evadewi, R., Meiranto, W. 2014. Pengaruh Pengungkapan Corporate Social Responsibility terhadap Earnings Management : A Political Cost Perspective. Diponegoro Journal of Accounting. 03(2).

Ghozali, I. 2016. Aplikasi Analisis Mulivariate dengan Program SPSS. Semarang : Badan Penerbit UNDIP. 
Hayu Wikan Kinasih, Melati Oktafiyani, dan Lenni Yovita :Keterkaitan Antara Corporate Social Responsibility Terhadap Manajemen Laba : Sebuah Perspektif Teori Agency

Healy, P., Wahlen, J. 2009. A Review of the Earning Management Literature and Its Implication for Standard Setting. Accounting Horizons.

Khan, A.R., Muttakin, M.B., \& Siddiqui, J. 2012. Corporate Governance and Corporate Social Responsibility Disclosures : Evidence from Emerging Economy. Journal of Business Ethics.

Kim, Y., Park, M.S., Wier, B. 2012. Is Earning Quality Associated with Corporate Social Responsibility? The Accounting Review.

Meutia, I. 2004. Pengaruh Independensi Auditor terhadap Manajemen Laba untuk KAP Big Five dan Non Big Five. Jurnal Riset Akuntansi. 3 (September).

Yip, E., Staden, C.V., Cahan, S. 2011. Corporate Social Responsibility Reporting and Earning Management : The Role of Political Costs. Australian Accounting, Business and Finance Journal. 5 (3).

Harga Penutupan Saham. www.idx.co.id. Diakses tanggal 6 November 2017.

Harga Penutupan Saham. www.sahamok.com. Diakses tanggal 8 November 2017.

Kasus Manajemen Laba. https://finance.detik.com/. Diakses tanggal 8 November 2017. 